\title{
Do-it-yourself digital: the production boundary, the productivity puzzle and economic welfare
}

Diane Coyle, University of Cambridge ${ }^{1}$

\section{Abstract}

Part of the debate about the 'productivity puzzle' concerns potential mismeasurement of GDP due to digital activities. This paper discusses some measurement issues arising from digitally-enabled substitutions in activity across the conventional production boundary. Production boundary issues are not new, as conventionally defined GDP statistics account for the monetary cost but not the time cost of consumption and production. This means changes in the way time is allocated between market and home production affect measured growth and productivity. Just as technological innovation in domestic appliances led to a substitution from home production into market consumption in the second half of the $20^{\text {th }}$ century, today's digital innovations are driving some reverse substitution out of the market into home production. Statistical agencies do not currently collect the data needed to measure the scale of the switch, but the available evidence suggests it may be enough to make a contribution to understanding the puzzling behaviour of measured productivity.

JEL codes: E01, C82, O40

Keywords: digital, production boundary, productivity, welfare

\footnotetext{
${ }^{1}$ This research was undertaken under the auspices of the Economic Statistics Centre of Excellence, supported by the Office for National Statistics. My thanks for their comments on earlier versions to David Byrne, Jagjit Chada, Carol Corrado, Anne Harrison, Jonathan Haskel, Richard Heys, Dale Jorgenson, Sanjiv Mahajan, Leonard Nakamura, Mary O’Mahony, Nick Oulton, Chris Payne, Rebecca Riley, Peter Sinclair, Rachel Soloveichik, Martin Weale, Peter Vandeven, Dominic Webber, and in addition two anonymous referees. Of course I am entirely responsible for any errors.
} 
Digital activities and business models are affecting the measurement of GDP, on existing national accounts definitions, in multiple ways. Digital change is causing a wide range of substitutions both within and across the production boundary as currently defined. Substitutions between economic activities occur constantly but the pace has likely increased thanks to the rapid spread of fixed and mobile broadband. Some of these digitally-enabled changes have potentially decreased conventionally measured real GDP and productivity (compared to a counterfactual world of no digital innovation) by reducing the time cost of home production and consumption of some goods and services. Substitution to unmeasured sectors experiencing faster productivity growth from measured sectors whose recorded productivity growth will consequently be lower explains the wedge between the actual and counterfactual productivity measures, similar to the phenomenon Griliches (1994) discusses in the context of 'unmeasurable' sectors (government and construction for examples). Productivity growth in these sectors is missed because it crosses the artefact of the production boundary, leaving slower productivity growth activities behind in what is measured.

Robert Gordon (2016) has challenged the idea that the new technologies are contributing much at all to either welfare or productivity. On the other hand, the digital sector insists the scale of recent innovation is such that the contribution of digital to the economy must be under-stated. ${ }^{2}$ It is surely the case that an explanation of recent productivity behaviour will involve many contributory factors, including overhang from the financial crisis and long-term structural issues such as demographic change. But it would nevertheless be surprising if the significant behavioural changes by businesses and households, arising from the spread in the UK and other OECD countries of broadband internet (from 2000) and very rapid take-up of smartphones and mobile internet (from 2007), with evident effects on production and consumption behaviours, had not had any significant impact on the economy.

Digital change poses numerous challenges for the collection and interpretation of economic statistics, ranging from ensuring newer businesses and activities are included in data collection to difficulties in taking due account of quality change in goods and services. The range of these challenges was set out in the UK's Independent Review of Economic Statistics, and addressing them is at the centre of the strategic plan of the Office for National Statistics (Bean 2016, ONS 2016d, Coyle 2015). Previous research has considered some potential contributions from technological change to the 'productivity puzzle' observed in most OECD economies since around 2008, and found them to be relatively small (for example, Ahmad \& Schreyer 2016, Byrne et al 2016, Syverson 2016). For instance Byrne et al (2016) concluded the effects of quality change in ICT products and services are too small for careful hedonic adjustment to account for the break in trend productivity (in particular as the size of the ICT goods and services sector is small).

Yet these conclusions on the face of it seem at odds with the dramatic extension in the diffusion and use of new technologies by households and businesses. To explore the question of whether measurement artefacts might contribute to understanding the slowdown in measured real GDP and

\footnotetext{
${ }^{2}$ See for example Aeppel 2015, ONS 2016c, Varian 2016.
} 
productivity growth, the focus here is on the switching of economic activity across the production boundary as currently defined in the System of National Accounts (SNA). Online activities undertaken by the household sector and substituting for marketed activities have been growing. The phenomenon may make a contribution to explaining the 'productivity puzzle' to the extent that, compared to the counterfactual of a non-digital world, consumers are switching from purchasing some marketed outputs to home production. These home produced digital activities should therefore at a minimum be measured more fully in the household 'satellite' account; given their rapid expansion, they require more careful measurement to inform assessments of economic welfare and policy.

The fact that clearly productive online activities are occurring on the non-market side of the boundary also raises the question of the interpretation of measured real GDP in the existing national accounts framework. This goes back to the original fundamental debate about the purpose of GDP: is it simply an aggregate monetary measure of marketed activity? In this case the issues raised here are irrelevant. Or is it intended to be a measure of economic welfare (as it is in fact always used), in which case the national accounts should take more careful account of the various digital substitutions? The first approach has broadly prevailed since the 1940s (Coyle, 2014; Mitra-Kahn, 2011). Consumer surplus gains have by definition never been captured in (nominal) GDP because it simply measures transactions at market prices. Many national accountants continue to insist this is the correct approach, and that it is a conceptual mistake to try to account for welfare changes in GDP. For example, Ahmad and Schreyer (2016) point out that production boundary issues are not new conceptually, and neither is the creation of unmeasured consumer surplus by innovations. Bos (2017) writes, "The successive guidelines all agreed that national accounts should not aim at measuring welfare, but focus on serving as a practical tool for macro-economic policy issues," while noting that there have been repeated calls over the decades for an economic welfare measure.

Yet almost all policy debate uses GDP as an indicator of economic welfare. Indeed, as soon as the nominal figures are adjusted for price changes there is an implicit welfare judgment - why, otherwise, should there be any attempt to hedonically adjust prices, as the very idea of 'quality change' goes directly to underlying preferences? Recent research (Brynjolfsson et al, 2017) aiming to measure directly this consumer surplus from digital innovation suggests it is large. Taken together, the scope of the substitutions discussed here, and of substitutions, new products and quality change occurring within the production boundary, is likely to be significant. Some of the individual substitutions would tend to reduce rather than increase the measures of labour or multifactor productivity on current definitions, so it is not apparent without much statistical work that they will entirely resolve the productivity 'puzzle'. At a minimum many of them have implications for the construction of deflators (see for example Abdirahman et al 2017, Reinsdorf and Schreyer 2017). These mean nominal GDP may be overdeflated, and real GDP growth and productivity therefore under-stated. ${ }^{3}$ To the extent that the bias in deflators has increased over time, this could contribute to unpicking the productivity puzzle.

\footnotetext{
${ }^{3}$ Throughout I use 'real' and 'nominal' as shorthand in place of the terminology of the SNA, 'in volume terms' and 'in current price terms' respectively.
} 
Here I focus not on prices but on a different aspect of assessing economic welfare, drawing on the insights of Gary Becker (1965) concerning the allocation of time between market and home production. As Becker notes, the time needed for the consumption of services in particular never enters conventional productivity calculations yet technological advances speed up some consumption activities and alter the market goods provided by service industries. He gives the example of barber shops: when home safety and electric razors became available, people saved time (walking to the barbershop and back, queuing, speed of shave) by buying razors and shaving themselves at home. Barbers switched the services they provided to haircuts. The recorded productivity of barbershops did not increase; but there was significant productivity gain in the production of shaves. He surmises that this effect may go some way to explain the slow growth in the measured productivity of many service sectors compared with goods-producing sectors. The digital technology is similarly making it less costly (in terms of total time plus money cost) to produce some services in the home rather than purchasing them in the market.

This debate is central to the practical question of what statistical offices should be doing in response to the digital changes that form some of the most visible features of current developments in the OECD economies, and yet are scarcely measured as yet in official economic statistics. It also speaks both to the policy interpretation of productivity statistics, and also to the increasingly often-expressed dissatisfaction with GDP growth as a yardstick for economic policy.

\section{Production boundary paradoxes in the national accounts framework}

A key decision in defining GDP in the present System of National Accounts was where to draw the line in terms of what is included and excluded. Broadly speaking, this production boundary distinguishes paid-for activities in the market economy from unpaid activities, which are considered outside the productive sector. However, there are activities that by convention cross the boundary. The obvious one is that government activity is included in GDP although by definition it is not in the market, a decision intensely debated both in principle in the early days and in terms of detailed practice in the implementation of successive SNA revisions. ${ }^{4}$ In the present national accounts framework, broadly speaking firms and the government are considered producers for the purposes of inclusion in GDP, and households are not (although non-marketed productive activity takes place within households and unincorporated enterprises are included in the household sector).

The production boundary is defined in the following way. Included are:

a. Goods and services produced for supply to 'units' other than their producers;

b. Own-account production of goods retained by their producers for final consumption or capital formation;

\footnotetext{
${ }^{4}$ Mitra-Kahn (2011) surveys the debate; on this point see also Lacey (2011); Studenski (1958) Chapter 14; Vanoli (2005) p249ff.
} 
c. Own-account production of knowledge-capturing products retained by their producers for final consumption or capital formation (but excluding such products produced by households for their own use eg family photos);

d. Own account production of housing services by owner occupiers;

e. Production of domestic and personal services by paid domestic staff.

Own-account production of services is excluded on the grounds that these have 'limited repercussions on the rest of the economy,' changes in their level do not affect the economy's tax yield, and there are no market prices at which to value these services (SNA 2008, paras 6.27-6.30). As noted below, this reasoning seems at odds with the growth of market production and consumption of many household services from the 1950s, leading to significant (and in some countries continuing) shifting of activity across the production boundary since the 1970s.

Conceptually, the household can be considered a production unit combining inputs of its own time (labour), household capital assets (ovens, cars, washing machines), and purchased intermediate or final goods and services, to produce or secure a range of final goods and services which in the majority of instances the household itself consumes, but which can also enter the productive economy (Becker 1965, Abraham and Mackie 2005). There is a range of possible choices, for example from growing vegetables and cooking everything from scratch at home, to buying food and hiring a cook or eating all meals in restaurants. Over time, as real wages for work outside the home have increased, innovations in domestic technology have substituted for labour in the home, and social change has led more women to work in paid employment, the opportunity cost of home production has increased, and substitution from home production to market production has occurred (Parente, Rogerson and Wright, 2000). Investment in domestic capital also increased household labour productivity.

As described above, the production of goods by households for their own consumption is by convention included in the definition of GDP, whether they are actually sold in the market or not. This reflects the importance of own-production of food and clothing, for instance, in low-income economies. "When the amount of a good produced within households is believed to be quantitatively important in relation to the total supply of that good within the country, its production should be recorded," (SNA 2008 §6.233). Goods such as these were considered 'near market' as a third party would be able to provide them to the household; and there would be market prices enabling them to be valued. However, the production of services (childcare, cooking, cleaning and so on) for own-consumption is excluded (although services provided by paid domestic staff are counted in GDP). The distinction, or 'nearness' to market of own-produced goods as opposed to services was much debated in the early days of the establishment of national accounting standards. In his classic history, Paul Studenski (1958) wrote: "Most scholars favour, in principle, the inclusion of the unpaid services of the housewife in national income. The difficulty, however, consists in finding a fair measure of the economic value of the housewife's services," although he added the caution that care should be taken not to try to annex too many own-account activities to national income (Studenski, p177, italics in original). Such services are productive, in that they are provided for other people, but not counted within the SNA production boundary. 
Finally, the 'own-account production of housing services by owner-occupiers' is included in GDP, in the form of an imputed value for the market rent owner occupiers would otherwise have to pay for housing. ${ }^{5}$ Studenski noted that an imputation for owner occupied housing services had not previously been widely included in definitions of national income. From 1944, however, it was incorporated into the international standard: "Home ownership was assumed to be a business, producing services that are sold to the home owner in his capacity as tenant," (Studenski p178). While almost certainly pragmatically motivated by the fact that the UK (a key player in the postwar national accounting debates) levied tax on the imputed rental of owner-occupied housing until 1963/4 (the 'Schedule A' income tax), this change was justified with reference to the obvious ease of switching between owning and renting, and the potentially large impact on measured GDP of decisions to switch mode of occupation. There is no difference in principle from the decision to go to a launderette rather than use the washing machine at home, but the boundary between owning and renting a house can be easily identified (and moreover there is a difference of scale, which is not relevant in theory but does matter for practical statistical purposes). This component of GDP consists of a non-monetised service derived from household capital; this is the only household capital asset currently accounted for.

As Vanoli (2005, p242) summarises it, with the prominent exception of imputed rental of owner occupied dwellings: "GDP is defined in the SNA in such a way as to represent the aggregated value of the production of goods and services within the field of socially organized employment." The definitions have evolved over time - for example in the inclusion in principle since the 1993 SNA (and 1995 ESA) of the production of illegal, marketed activities. However, definitional decisions concerning the production boundary have often been challenged. Feminist scholars have long noted that the goods/services distinction in home production ensures activities mainly performed by women are not measured, to the detriment of social policy decision-making (Waring 1988, Folbre \& Nelson 2000). The value of leisure as a component of economic welfare is not reflected in GDP either, although there have been attempts to capture this. Nordhaus and Tobin's well-known 'Measure of Economic Welfare' estimated the value of leisure to be the same order of magnitude as conventionally measured GDP, when valued at market wage rates to reflect the opportunity cost (Nordhaus and Tobin 1972). A more recent economic welfare measure indicates that whereas the United States has large advantage over other rich OECD economies in terms of real GDP per capita, incorporating leisure (as well as mortality and inequality) into a welfare-enhanced GDP measure almost closes the international gap, indicating the importance of choices on these margins for economic welfare comparisons (Jones \& Klenow 2016).

\section{Why there is a household satellite account}

These longstanding concerns about omissions from GDP have been addressed by the development of satellite accounts. Satellite accounts measure areas of activity at least in part excluded from the 'core'

\footnotetext{
${ }^{5}$ http://unstats.un.org/unsd/nationalaccount/sna2008.asp
} 
SNA because they are outside the production boundary. Eurostat first put forward methodological proposals for a household satellite account (HHSA) covering own-account production and consumption in 1999, and the ONS followed up with detailed methodological proposals and its first experimental estimates in 2002 (Holloway et al 2002). ${ }^{6}$ One source of data for the HHSA is a time use survey, which is combined with appropriate methods for valuing the time households spend on each kind of activity. ${ }^{7}$ Table 1 illustrates time use patterns but unfortunately time use surveys are not conducted regularly, and there are issues of quality and comparability over time in the results. ONS also implements an output approach in the HHSA as recent time use surveys are unavailable, aiming to measure directly the services provided rather than measuring the labour input to produce them. In order to value home produced services, when by definition no market price is available, the alternatives are to use: market wage rates to apply to time use data; the opportunity cost of the labour time involved; or the price of a near-market alternative (Abraham and Mackie 2005, Chapter 3).

Table 1: Time use patterns - an illustration

\begin{tabular}{|c|c|c|c|}
\hline & All & $\begin{array}{ll}\begin{array}{l}\text { Employed } \\
\text { hours/week }\end{array} & 30-49 \\
\end{array}$ & $\begin{array}{l}\text { Caring for } \\
\text { family/homemaker }\end{array}$ \\
\hline \multicolumn{4}{|l|}{ Minutes per day } \\
\hline Employment & 176 & 305 & 8 \\
\hline Commuting & 21 & 37 & 1 \\
\hline Job search & 0 & 0 & 0 \\
\hline School/study & 15 & 5 & 4 \\
\hline Volunteering & 11 & 8 & 15 \\
\hline Eating \& personal & 134 & 119 & 133 \\
\hline Childcare & 20 & 17 & 95 \\
\hline Housework/shopping & 173 & 128 & 286 \\
\hline Socialising/entertain & 63 & 58 & 62 \\
\hline Exercise/sport & 14 & 14 & 10 \\
\hline Hobbies \& games & 21 & 18 & 14 \\
\hline Mass media & 184 & 150 & 169 \\
\hline Sleep & 508 & 499 & 526 \\
\hline Other & 100 & 83 & 117 \\
\hline Total & 1440 & 1440 & 1440 \\
\hline
\end{tabular}

Extracted from Table1, Labour Market Trends, February 2004, based on 2000 time use survey

ONS published a second full UK HHSA in 2016, using both time use data and a range of survey and administrative data to estimate output. ${ }^{8}$ The HHSA covers the value of adult and childcare, household housing services, nutrition, clothing and laundry, transport (any privately provided non-leisure transport such as commuting, shopping, school run), and volunteering. ${ }^{9}$ The activities included were selected according to the 'third party criterion', in other words whether a third party could provide these services in the market (Reid 1934). This excludes therefore self-care and leisure. Table 2 sets out

\footnotetext{
${ }^{6}$ See http://ec.europa.eu/eurostat/en/web/products-statistical-working-papers/-/KS-CC-03-003 for more on Eurostat's approach.

${ }^{7}$ ONS carried out UK time use surveys in 2000/01 and 2014/15. Most recent UK data are available from Gershuny et al (2017), UK Data Service. In the US the Bureau of Labor Statistics conducts time use surveys on an ongoing basis, https://www.bls.gov/tus/.

${ }^{8}$ The 2016 ONS HHSA (in absence of up-to-date time use data) was estimated using the output approach, using a range of survey or admin data sources to create estimates based on units of service produced $x$ price per unit. When time use data is used then the input approach can be used: hours worked $x$ market wage rate (plus any adjustments for market equitv tax/subsidies and gross operating surplus).

${ }^{9}$ https://www.ons.gov.uk/releases/householdsatelliteaccounts2011 to2014
} 
the relationship between the SNA 'core' and the household satellite, with the lightly shaded boxes lying inside the production boundary and therefore included in GDP. Nominal values for the UK in 2014 are also given in the table.

Table 2: Relation of household satellite account to core National Accounts

\begin{tabular}{|c|c|c|c|c|c|}
\hline 'Core' SNA & \multicolumn{5}{|c|}{ Household satellite account } \\
\hline \multicolumn{4}{|c|}{$\begin{array}{l}\text { SNA production } \\
(£ 1817.3 \mathrm{bn})\end{array}$} & \multicolumn{2}{|c|}{$\begin{array}{c}\text { Non-SNA production } \\
(£ 1018.9 \mathrm{bn})\end{array}$} \\
\hline \multirow{2}{*}{$\begin{array}{l}\text { Market } \\
\text { production }\end{array}$} & \multirow{2}{*}{$\begin{array}{l}\text { Voluntary } \\
\text { production } \\
\text { (goods) }\end{array}$} & \multicolumn{3}{|c|}{ Household production for own use } & \multirow{2}{*}{$\begin{array}{l}\text { Voluntary } \\
\text { production } \\
\text { (services) } \\
\text { (£23.3bn) }\end{array}$} \\
\hline & & $\begin{array}{l}\text { Own } \\
\text { account } \\
\text { production } \\
\text { of goods } \\
(£ 0.2 \text { bn) }\end{array}$ & $\begin{array}{l}\text { Housing } \\
\text { services } \\
\text { produced by } \\
\text { owner- } \\
\text { occupiers } \\
(£ 177 \text { bn) }\end{array}$ & $\begin{array}{l}\text { Services } \\
\text { produced for own } \\
\text { use: } \\
\text { childcare } \\
\text { ( } £ 320.6 \text { bn) } \\
\text { adult care } \\
\text { (£56.9bn) } \\
\text { housing services } \\
\text { (£149.7bn) } \\
\text { nutrition } \\
\text { (£144.3bn) } \\
\text { clothing/laundry } \\
\text { ( } 55.6 \text { bn) } \\
\text { transport } \\
\text { (£235.8bn) }\end{array}$ & \\
\hline $\mathrm{A}$ & $\mathrm{B}$ & $\mathrm{C}$ & $\mathrm{D}$ & $\mathrm{E}$ & $\mathrm{F}$ \\
\hline
\end{tabular}

Source: Table from Eurostat 2003; figures are for 2014, from ONS 2016a. Note that 'housing services produced by owner occupiers' refers to imputed rent for living in the property; 'housing services' in the non-SNA category refers to DIY delivery of building maintenance.

Substitution has always occurred between activities included in GDP and excluded from it. Since the 1950s there has been growing substitution from own-use production of services such as nutrition and childcare to purchases of such services in the market, as the proportion of women engaged in paid employment has risen. For example, as $40 \%$ of lone-parents of under-fives work and $62 \%$ of couples with under-fives are both employed, use of marketed childcare is clearly extensive. Households' recorded annual expenditure on 'nursery, crèche, playschools \& childcare payments' was $£ 4.7 \mathrm{bn}$ in 2014, while public expenditure on child care (including tax credits) was $£ 5.2 \mathrm{bn}$. In the latest HHSA estimates, the gross value added of all childcare services in the home was $£ 320.6 \mathrm{bn}$, and output of childcare services in the home for children under five was $£ 132 \mathrm{bn}$ (32.5bn hours $\mathrm{x} £ 4.06$ per hour in the 2014 HHSA estimates). The value of own-account childcare services is thus greater than the 
imputed rental for living in owner-occupied housing. ${ }^{10}$ The logic of substitutability - albeit a choice made before production rather than after in the case of services - could argue for some of these other categories of home production being placed on the GDP side, or alternatively for removing the imputed rental of owner occupied dwellings from GDP and putting it with other home-produced services in the HHSA.

\section{Digital home production}

Here, however, I focus on new kinds of household production involving digitally-enabled activities. In $2017,90 \%$ of adults in the UK had home internet access and $80 \%$ go online daily (up from 57\% and $35 \%$ respectively in 2006). The average time spent online in March 2017 was 83 hours during the month. Among the 50 million estimated online users in the UK, 69\% said they engaged in online shopping, 63\% online banking (and a third said they did this at least once a month), 30\% uploading or creating online content. ${ }^{11}$ These figures have been increasing steadily since ONS and Ofcom started their surveys; these are not minor activities but a significant part of the lives of the majority of UK consumers.

The Bean Review noted that there has been an increase in households performing for themselves online services previously purchased in physical stores, such as booking holidays or undertaking banking transactions; there is still a supplier of a marketed service (although the identity of the intermediary may have changed from a traditional high street agent to an online platform). Some elements of the service (such as search and assembly of holiday packages) are performed by the individual using a domestic asset (a home computer or device) and inputs (an internet connection). Participation in the 'sharing economy' may also be increasing production activities by households for sale in the market, involving the use of household assets such as dwellings and cars as well as labour. Thirdly, many individuals are contributing voluntary digital labour to provide digital services/products in effect as public goods, which households and businesses may be substituting for purchased alternatives; examples include coding open source software, and creating user-generated content. I consider these three in turn below.

Becker's (1965) model of time allocation, bringing together the household production and the market consumption and production decisions, helps frame the discussion. Households combine time and market goods to produce basic commodities $\mathrm{Zi}_{\mathrm{i}}$

\footnotetext{
${ }^{10}$ Family Spending, Table A1

https://www.ons.gov.uk/peoplepopulationandcommunity/personalandhouseholdfinances/incomeandwealth/compen dium/familyspending/2014-12-02/familyspending2014referencetables; https://www.publications.parliament.uk/pa/ld201415/ldselect/ldaffchild/117/11706.htm

${ }^{11}$ ONS Internet Access Survey 2017

https://www.ons.gov.uk/peoplepopulationandcommunity/householdcharacteristics/homeinternetandsocialmediausa ge/bulletins/internetaccesshouseholdsandindividuals/2017 Ofcom technology tracker, https://www.ofcom.org.uk/ data/assets/pdf file/0021/105438/uk-internet-online.pdf
} 


$$
\mathrm{Z}_{\mathrm{i}}=\mathrm{f}_{\mathrm{i}}\left(\mathrm{x}_{\mathrm{i}}, \mathrm{T}_{\mathrm{i}}\right)
$$

where the $\mathrm{x}_{\mathrm{i}}$ is a vector of market goods (including capital services of durable goods) and $\mathrm{T}_{\mathrm{i}}$ is a vector of time inputs (such as weekday hours, weekend hours, nighttime hours) used in producing market commodities, and the partial derivatives of $\mathrm{Z}_{\mathrm{i}}$ with respect to both inputs are non-negative. Rewriting the production functions,

$$
\begin{aligned}
& \mathrm{T}_{\mathrm{i}}=\mathrm{t}_{\mathrm{i}} \mathrm{Z}_{\mathrm{i}} \\
& \mathrm{X}_{\mathrm{i}}=\mathrm{b}_{\mathrm{i}} \mathrm{Z}_{\mathrm{i}}
\end{aligned}
$$

The $t_{i}$ and $b_{i}$ are vectors giving the time and market goods inputs per unit of $Z_{i}$. Households combine the inputs via these household production functions to maximise utility

$$
\mathrm{U}=\mathrm{U}\left(\mathrm{Z}_{1}, \ldots \mathrm{Z}_{\mathrm{m}}\right)
$$

in the usual way, subject to budget constraint where $\mathrm{Z}$ is the bound on resources $Z_{i}$, and $g$ the expenditure function

$$
\mathrm{g}\left(\mathrm{Z}_{1}, \ldots \mathrm{Z}_{\mathrm{m}}\right)=\mathrm{Z}
$$

The expenditure function includes expenditure on both market goods and time; these are not independent because time can be converted into more market goods by spending more time at work and less in consumption. There is therefore a single constraint

$$
\Sigma \mathrm{p}_{\mathrm{i}} \mathrm{X}_{\mathrm{i} .}+\Sigma \mathrm{T}_{\mathrm{i}} \mathrm{W}^{\prime}=\mathrm{V}+\mathrm{T} \bar{w}
$$

where the $\mathrm{p}_{\mathrm{i}}$ are the prices of the market goods, and $\bar{w}$ is a vector of wages paid for hours of work in the different categories, and V is other income. Substituting in the production functions, (5) can be written as

$$
\Sigma\left(\mathrm{p}_{\mathrm{i}} \mathrm{b}_{\mathrm{i}}+\mathrm{T}_{\mathrm{i}} \bar{w}\right) \mathrm{Z}_{\mathrm{i}}=\mathrm{V}+\mathrm{T} \bar{w}
$$

Or in other words the full price of the goods consists of the sum of the prices of the market goods $\left(\mathrm{p}_{\mathrm{i}}\right)$ and time of different types $\left(\mathrm{T}_{\mathrm{i}}\right)$ used in production of the market goods. Behind these components of price lies an allocation of time to market work and consumption. Becker's barbershop example is just one among many. Many service activities have undergone various technological and business model changes over time, and these can move activities across the production boundary. Given the wide scope of the adoption and use of digital technologies in many service activities, it is evident that such shifts are occurring now. 


\section{Household production of digital intermediation services}

Turning to the first category of services where there is a production boundary effect due to digital, the activities in question include what might be labelled do-it-yourself digital intermediation services. These involve the substitution of online activity at home for some components of purchased services. Table 3 gives examples.

Table 3 Examples of household digital intermediation services

\begin{tabular}{|l|l|}
\hline Banking & $63 \%$ of UK adults used internet banking in 2016 \\
\hline Financial trading & $\begin{array}{l}\text { No estimate of numbers for normal personal } \\
\text { transactions eg via 'wrapper' platforms; many } \\
\text { 'day trading' services advertised and careers } \\
\text { advice available: https://www.reed.co.uk/career- } \\
\text { advice/how-to-become-a-day-trader/ }\end{array}$ \\
\hline Insurance broking & Many households search online for insurance \\
\hline Mortgage broking & Many households search online for mortgages \\
\hline Travel advice \& reservations & $\begin{array}{l}46 \% \text { used the web for travel or accommodation } \\
\text { services }\end{array}$ \\
\hline Estate agency & $\begin{array}{l}\text { Many households search online for properties; } \\
\text { there are some online-only estate agencies }\end{array}$ \\
\hline Employment agency & $\begin{array}{l}\text { 25\% used the web to look for a job or send a job } \\
\text { application }\end{array}$ \\
\hline Online search & $\begin{array}{l}\text { Almost everyone who is online - } 90 \% \text { of UK } \\
\text { households }\end{array}$ \\
\hline
\end{tabular}

Percentage figures are from ONS Internet Access Survey

The growth of the new 'do-it-yourself' digital intermediation services has certainly not wholly displaced market intermediation; indeed intermediary businesses such as banks and estate agencies see the web as another channel partly replacing their conventional high street engagement with consumers. There has been a change in the identity of the market intermediaries in some of these examples, with new online (sometimes overseas) intermediaries taking market share; but there are still market transactions taking place. Yet to some extent households themselves are carrying out some of the functions of the previous high street intermediaries, such as search in travel and estate agency, or transactions such as making payments and setting up standing orders in online banking. ${ }^{12}$ They also use their own domestic capital (computers, tablets or smartphones) as well as the capital (IT systems) of the intermediaries. To the extent that this is the case, it will have reduced measured revenues, output and employment in the affected sectors, and hence GDP, all else being equal (although of course household expenditure will have been reallocated away from travel agents to other items, including a portion of their broadband subscription payments).

Households do though have access to a wider choice and save some time compared with their predigital options, although just as with other own-production of services they contribute some of their own labour time to the activities. In addition, households are engaged in new kinds of online activities

\footnotetext{
${ }^{12}$ It might be objected that search is not a productive activity, so the digital intermediation in this respect has simply reduced a transaction cost. To the extent this is true, it was also not part of the marketed service provided by travel agencies etc., and their marketed activities are those replaced by household production.
} 
for which there were previously no (or only a few) market intermediaries. An example is online search not previously possible such as looking for films or restaurants before going out, or locating suppliers ('personal concierge activities'?). This could be a large effect; Varian (2016) has estimated that the value to consumers in the US of time saved through use of online search rather than going to a library or other alternatives is approximately $\$ 65$ bn annually. ${ }^{13}$ One could argue the internet has also made positive changes to the range and quality of the services the consumer can access, but at a fraction of the cost. While in theory this should be reflected in the national accounts, if the price deflator has been sufficiently adjusted to take account of the falling cost of a matched service, in practice this is not the case.

It is impossible to know from currently available statistics how much personal labour time is involved in supplying these own-account services. This seems an obvious information gap to be addressed by future time use surveys. It will almost certainly be less time than was involved in going to the high street and queueing. These activities would fall into the same category as other own-use services such as laundry, childcare etc (column E in Table 1). Their growth will probably have involved a switch away from marketed intermediation services, although many market providers will remain, offering a changing array of services through different business models (such as personal financial advice rather than straightforward counter transactions in banking).

Some idea of scale can be gleaned from looking at banking. As Figures 1 and 2 show, there has been a $34 \%$ decline in the number of physical bank branches since 2003 , and an increase from $30 \%$ to $63 \%$ in the proportion of people using online banking services between 2007 and 2017. This seems to indicate a quantitatively meaningful switch in activity across the production boundary in about a decade. Although disaggregated data for productivity growth are not available, the UK's finance sector has seen a decline of about $18 \%$ in its level of productivity since 2008 (EUKLEMS 2017).

Figure 1: Number of physical bank branches in the UK

\footnotetext{
${ }^{13} \mathrm{http}: / /$ cdn.oreillystatic.com/en/assets/1/event/57/The\%20Economic\%20Impact\%20of\%20Google\%20Presentatio n.pdf
} 


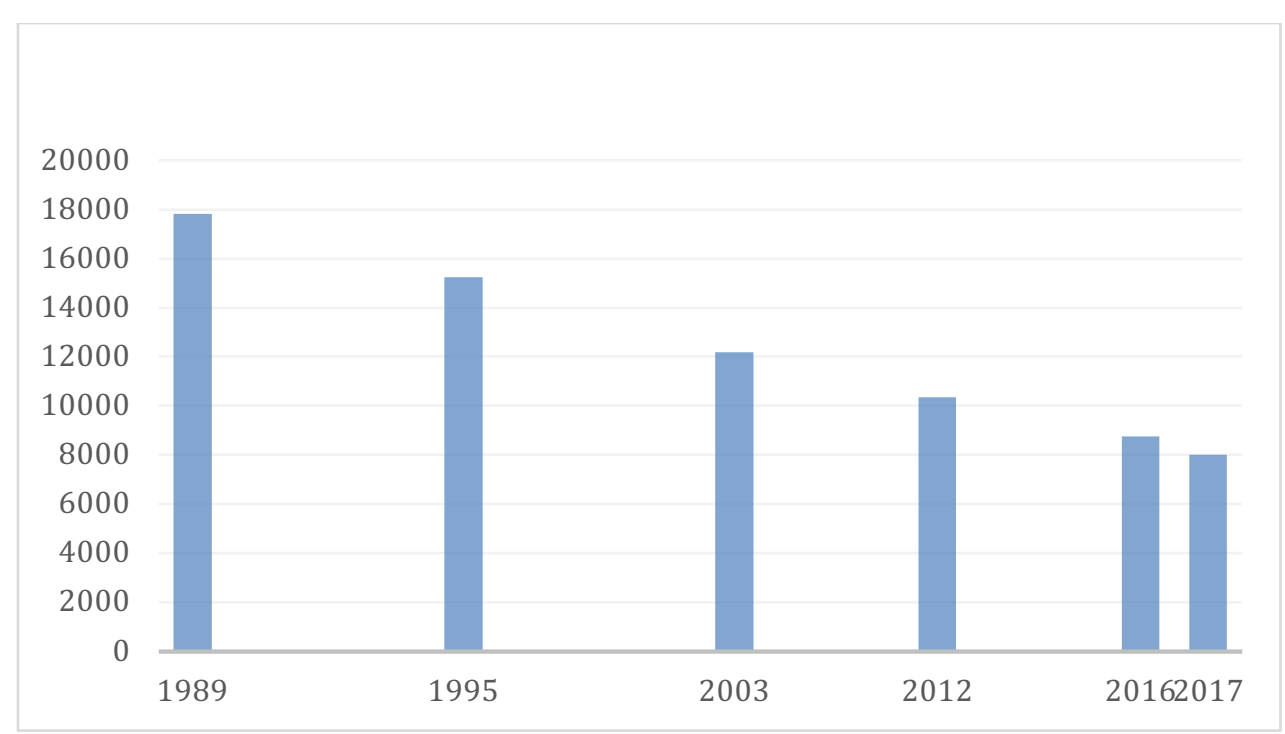

Source: French et al 2013; https://uk.reuters.com/article/uk-britain-banks-branches/british-banks-set-toclose-record-762-branches-this-year-idUKKCN1B31AY

Figure 2: Proportion of UK adults engaging in online banking

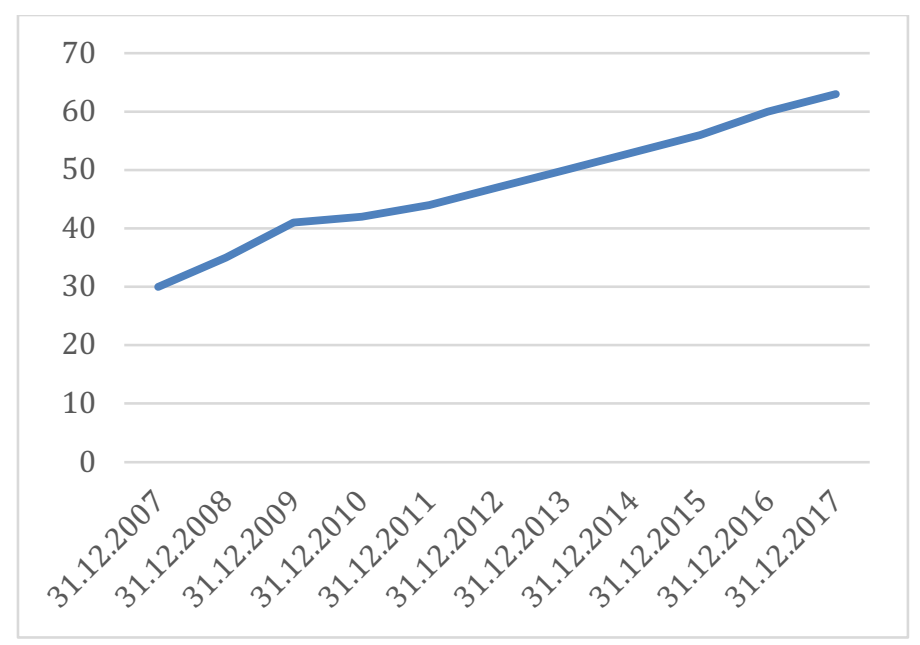

\section{Source ONS}

https://www.ons.gov.uk/peoplepopulationandcommunity/householdcharacteristics/homeinternetandsoci almediausage/datasets/internetaccesshouseholdsandindividualsreferencetables

\section{The 'sharing' economy}

A second set of household activities involving home produced but (sometimes) marketed activities is the 'sharing economy' (for which there is no firm definition, but covers peer-to-peer matching 
platforms). ${ }^{14}$ In Table 1 these conceptually sit in the final column (F) if non-marketed, while their value added (of the digital platform and the suppliers to the platform) sits in the first column (A) if sold in the market. ${ }^{15}$ Compared with the conventional businesses providing similar services (such as accommodation or taxi rides), the technology creates an intensive margin between home production and work in the market, as distinct from the extensive margin between home work and having a job.

Digital intermediation also increases the efficiency of matching, which is a clear increase in economic welfare to the extent that preferences and products are heterogeneous. There is also in principle an increase in the efficiency with which household capital assets are used - so for example, cars can stand idle less of the time, and fewer may be owned, releasing land currently used for parking. In addition, prices on sharing platforms are often lower than the prices of market equivalents. In the conventional national accounts framework, welfare increases not reflected in market prices are not captured in GDP, while the dynamics of improved capital efficiency are complicated and anyway currently small in scale.

ONS work to date has identified three categories of these market sharing economy activities, distinguished by output characteristics, set out in Table 4 .

Table 4: 'Sharing Economy' categories

\begin{tabular}{|l|l|}
\hline Property rental and access & Airbnb, LoveHomeSwap, JustPark \\
\hline Peer-to-peer services & Etsy, TaskRabbit, Lyft, Bookalokal \\
\hline Collaborative finance & Zopa, Veridu, Funding Circle \\
\hline
\end{tabular}

These also have different input mixes, with the first category involving more intensive use of household capital, the second more use of labour, and the third financial capital. There are in addition sharing activities that do not involve any financial transactions (such as Freecycle, Olio, or neighbourhood time banks), which will substitute for some marketed activities.

A big challenge is simply the collection of data on these activities. In the UK, the ONS has started collecting additional data, while new online data collection techniques may help in future. ${ }^{16}$ To measure peer-to-peer activities, the fee or commission revenues of the platforms (businesses such as Taskrabbit and Airbnb), the earnings of individual participants (drivers, hosts etc), and prices paid by users are all required. Another practical challenge is the extent to which these activities involve purchases of intermediate goods, which ought in principle to be netted out, and also use the services of household capital assets, of relevance when it comes to looking at productivity measurement. Just as business purchases of intermediate goods need ultimately to be netted off final revenues in the GDP figures, so with production for the market by households; and this is in fact done in some of the HHSA

\footnotetext{
${ }^{14}$ This nomenclature is controversial because it extends a term originally applied to non-marketed peer-to-peer activities such as time banking and Freecycle to monetary activities. The distinction between marketed and free is certainly key.

${ }^{15}$ Income on owner-occupied housing would also be set against the imputed rent component of GDP.

${ }^{16} \mathrm{https}$ ://www.ons.gov.uk/economy/economicoutputandproductivity/output/articles/thefeasibilityofmeasuringthesh aringeconomy/progressupdate
} 
categories. Extending this is a tall order: how for example could one begin to measure purchases of household cleaning products for use in cleaning a room rented out on Airbnb rather than for domestic use? However, there are new supply chain services emerging in the largest segments of the 'sharing economy', such as intermediaries that will look after cleaning and key transfer for properties. It will be more straightforward to collect this data.

When it comes to assets, at present owner occupied housing is the only household asset to feature in national account statistics, in the form of the imputed rental paid for the capital service. While housing is the largest asset by value owned by the household sector, many sharing economy activities involve the use of cars, computers, sewing machines, perhaps even 3D printers or domestic robots in future. All of these are productive durable assets providing a stream of services. Some authors have long argued for including these services in their growth accounting calculations (for example, Jorgenson 2009). As long as such peer-to-peer activities within the household sector remain small scale, the omission of capital services from household assets may not be significant. If they were to grow, this would be an issue for estimates of multifactor productivity.

The sharing economy has been growing rapidly. ONS figures suggest many people use such platforms $-28 \%$ and $22 \%$ of UK adults used accommodation platforms and ride sharing platforms respectively in $2017^{17}$ - but the extent to which they use them is not known. Reflecting the technological possibility of greater flexibility in time allocation, 'contingent' employment patterns in general are becoming more widespread: although there is no definitive way of measuring it, relevant indicators such as selfemployment, zero hours contracts, and industry figures point to significant expansion in the past decade (Coyle 2017a)

Furthermore, the prices charged by sharing platforms have not to date been included in the sampling for consumer price indices, and even if they were now to be included through the usual matching process or as a new good, the resulting index would omit a substantial part of the price reduction available (Groshen et al, 2017). It is clear that prices on accommodation platforms, for instance, can be considerably lower than hotel room process. For example, Figure 3 compares the average daily rate received by Airbnb hosts and the average daily rate for hotel rooms in London in late 2014 to mid-2016 (Coyle \& Yeung, 2017). While not identical products, the price gap is substantial.

Figure 3: Average daily rate received, Airbnb room, single hotel room

17 https://www.ons.gov.uk/peoplepopulationandcommunity/householdcharacteristics/homeinternetandsocialmediausa ge/datasets/internetaccesshouseholdsandindividualsreferencetables 


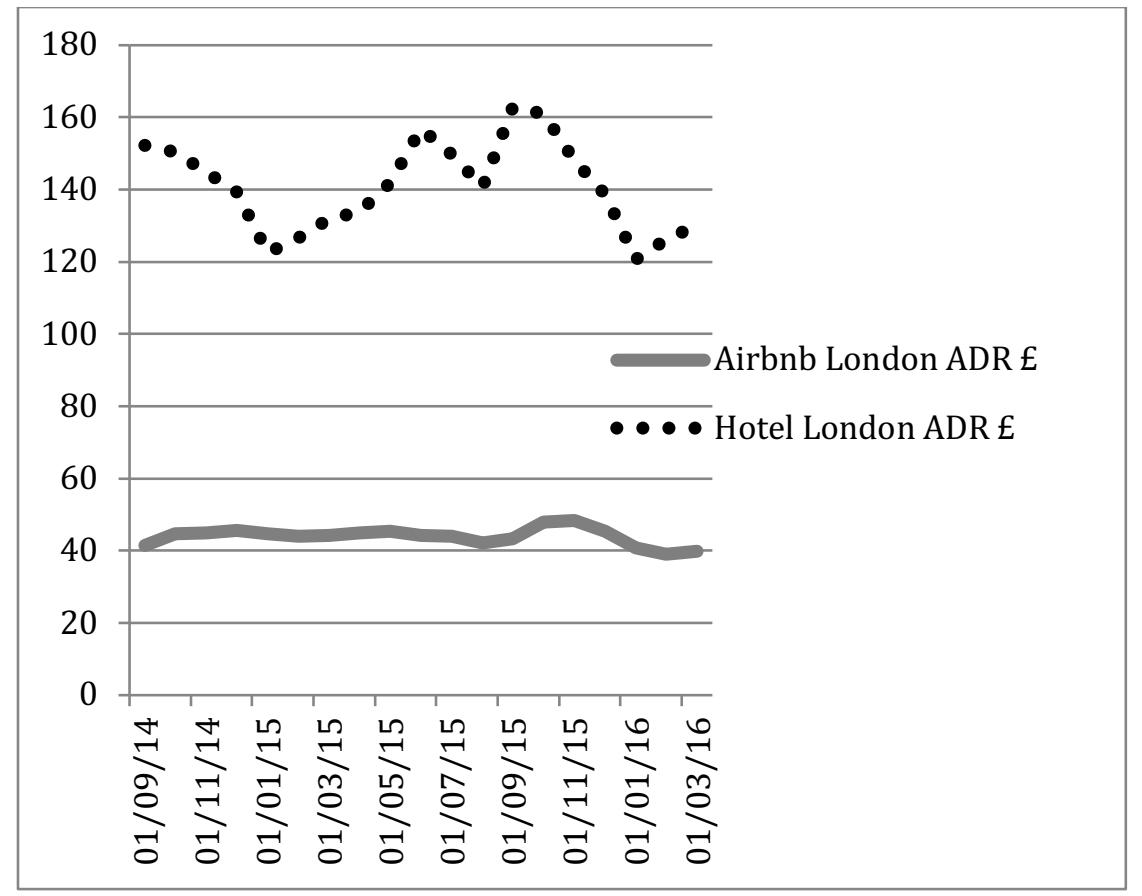

Source: Airbnb data provided by Airdna; hotel data provided by STR.

\section{Voluntary digital production}

The third category of household production where digital is starting to have a big impact is in the voluntary provision of digital outputs. There is category of free digital services or products provided by individuals, although to some extent individuals may seek to monetise these activities, for example by signing up to receive advertising revenue from videos uploaded to YouTube, or increasing future earnings through raising their status in online fora. ${ }^{18}$ Table 5 gives examples.

Table 5 Examples of unpaid digital provision

\begin{tabular}{|l|l|l|l|}
\hline Type & Examples & $\begin{array}{l}\text { Marketed } \\
\text { substitutes }\end{array}$ & Scale? \\
\hline $\begin{array}{l}\text { Open source } \\
\text { software }\end{array}$ & $\begin{array}{l}\text { R, Python, } \\
\text { Apache, Linux, }\end{array}$ & $\begin{array}{l}\text { Proprietary } \\
\text { software eg } \\
\text { Windows, Stata, } \\
\text { IOS }\end{array}$ & $\begin{array}{l}\text { Linux largest installed base of } \\
\text { general operating systems; About } \\
50 \% \text { of web servers globally run } \\
\text { Apache. For growth in use of R } \\
\text { see } \\
\text { http://r4stats.com/articles/popularit } \\
\text { y/ }\end{array}$ \\
\hline $\begin{array}{l}\text { Online software/tech } \\
\text { advice }\end{array}$ & $\begin{array}{l}\text { Stack Overflow, } \\
\text { SourceForge, } \\
\text { GitHub,... }\end{array}$ & $\begin{array}{l}\text { Consultancy, } \\
\text { software services }\end{array}$ & $\begin{array}{l}\text { "With the tools we provide, } \\
\text { developers on SourceForge create } \\
\text { powerful software in over 430,000 } \\
\text { projects; we host over 3.7 million } \\
\text { registered users. Our popular } \\
\text { directory connects more than 41.8 } \\
\text { million customers with all of these } \\
\text { open source projects and serves } \\
\text { more than 4,800,000 downloads a }\end{array}$ \\
\hline
\end{tabular}

\footnotetext{
${ }^{18}$ There is no resolution to the long debate about whether advertising should be treated as intermediate or final consumption. See Kaldor (1940); Harrison (1999); also Nakamura and Soloveichik (2015) for a discussion of adfunded digital media more generally.
} 


\begin{tabular}{|c|c|c|c|}
\hline & & & day" \\
\hline $\begin{array}{l}\text { Writing/editing } \\
\text { online material }\end{array}$ & Wikipedia; blogs & $\begin{array}{l}\text { Purchased reference } \\
\text { works, books, } \\
\text { magazines etc }\end{array}$ & Millions of volunteer producers \\
\hline $\begin{array}{l}\text { Uploading videos, } \\
\text { other entertainment }\end{array}$ & $\begin{array}{l}\text { YouTube; social } \\
\text { media }\end{array}$ & $\begin{array}{l}\text { Purchased } \\
\text { entertainment }\end{array}$ & $\begin{array}{l}300 \text { hours uploaded to YouTube } \\
\text { every minute; } 3.25 \text { billion hours } \\
\text { watched globally per month. } \\
\text { Average } 6 \text { hours/week spent on } \\
\text { Facebook. }\end{array}$ \\
\hline $\begin{array}{l}\text { Other advice, } \\
\text { discussion forums }\end{array}$ & $\begin{array}{l}\text { MumsNet, health } \\
\text { advice forums }\end{array}$ & $\begin{array}{ll}\begin{array}{l}\text { Subscriptions } \\
\text { clubs }\end{array} & \text { to } \\
\end{array}$ & \\
\hline Educational material & $\begin{array}{l}\text { Khan Academy, } \\
\text { CORE } \\
\text { Economics, } \\
\text { lecture videos and } \\
\text { podcasts }\end{array}$ & Textbooks, tutors & $\begin{array}{l}\text { Khan Academy used by } 2 \mathrm{~m} \\
\text { teachers and } 40 \mathrm{~m} \text { students } \\
\text { monthly. Number of free } \\
\text { educational downloads from } \\
\text { iTunes U passed } 1 \mathrm{bn} \text { in } 2013 \text {. }\end{array}$ \\
\hline $\begin{array}{l}\text { Crowdsourced } \\
\text { information, user- } \\
\text { generated content }\end{array}$ & $\begin{array}{l}\text { Waze, congestion } \\
\& \quad \text { travel } \\
\text { information }\end{array}$ & $\begin{array}{l}\text { Local radio; or not } \\
\text { previously available }\end{array}$ & \\
\hline $\begin{array}{l}\text { User/open innovation } \\
\& \text { design }\end{array}$ & & $\begin{array}{l}\text { Did not previously } \\
\text { occur - serves } \\
\text { initially small } \\
\text { markets, may be } \\
\text { commercialised as } \\
\text { the markets grow }\end{array}$ & $\begin{array}{l}\text { Von Hippel's (2017) surveys } \\
\text { suggest quantity is extensive. } \\
\text { Some likely to remain non- } \\
\text { commercialised as potential } \\
\text { markets are small. }\end{array}$ \\
\hline
\end{tabular}

As with household production for own-use, the time spent on these activities and its valuation could be accounted for, although there are important caveats. For example, the distinction between leisure and productive activity for use by others is not at all clear in some of these examples. Some of the reallocation of time will be from leisure (rather than paid work) to home production. The valuation of time spent on digital production would probably be higher than the valuation of time spent on leisure alternatives if using a market substitute approach; but valuation is particularly tricky because many of these zero priced products are public goods (non-rival in consumption) and also durable (able to be consumed over long periods) although intangible.

There is also perhaps a question as to whether household provision of these unpaid digital activities to other parties should be considered as household provision of voluntary services $(\mathrm{F})$, or as household provision of goods with close market substitutes (D); and it may differ by category. Typical voluntary services have included examples such as working in a local charity shop, volunteering in schools, or acting as a trustee or governor. In the recent HHSA, their estimated value was relatively small.

What is the right way to treat these unpaid digital outputs? Some economists have argued that they are an economically efficient mode of production of goods and services in contexts where information asymmetries and transaction costs inhibit either market or managerial organisation of production, but individuals have sufficient motivation to produce for 'the commons' (Lerner \& Tirole 2005, Benkler 2002). The interaction of the household commons with market activities in the national accounts is more complicated than the straight substitution of own-use provision for marketed alternatives. What's more, the scale of these activities could be large, but it is difficult to assign them to a national territory. 
However, they are often close substitutes for marketed digital and non-digital products classed as goods (packaged software, encyclopaedias, books and magazines, DVDs). They could be marketed after production, just like other products that straddle the production boundary.

There are no readily available statistics on either personal or business use of these various digital products provided for free, and to construct estimates would involve a very challenging data collection and valuation programme. However, the scale seems likely to be large. Greenstein and Nagle (2014) estimate that the use of just one product, Apache, in the US equates in value to between $1.3 \%$ and $8.7 \%$ of the stock of private investment in pre-packaged software. There is ample anecdotal evidence of for instance the rapidly growing use of open source software, including by large companies such as Walmart and Netflix. ${ }^{19}$ The cost savings businesses can make by switching to open source software are significant. ${ }^{20}$ Tallying downloads of the different forms of free software and estimating the impact on proprietary alternatives is nigh on impossible, but some suggestive evidence is provided by Robert Muenchen (2017). He presents figures on the number of articles listed on Google Scholar on the top six proprietary packages. These and other indicators (such as job listings and some downloads data) point to possible substitution from market to free (Figure 4).

Even if some definitive raw statistics were available, the problem of assignment within the national accounts and satellite accounts would be made more complex by the fact that household contributions merge inextricably with foundations and non-profits. For instance, two New Zealand university lecturers originally developed the R software, although other individuals were responsible for much of the subsequent development, while Apache was created by a group of friends who later formed their joint enterprise into a non-profit foundation.

Figure 4: Top six proprietary software packages

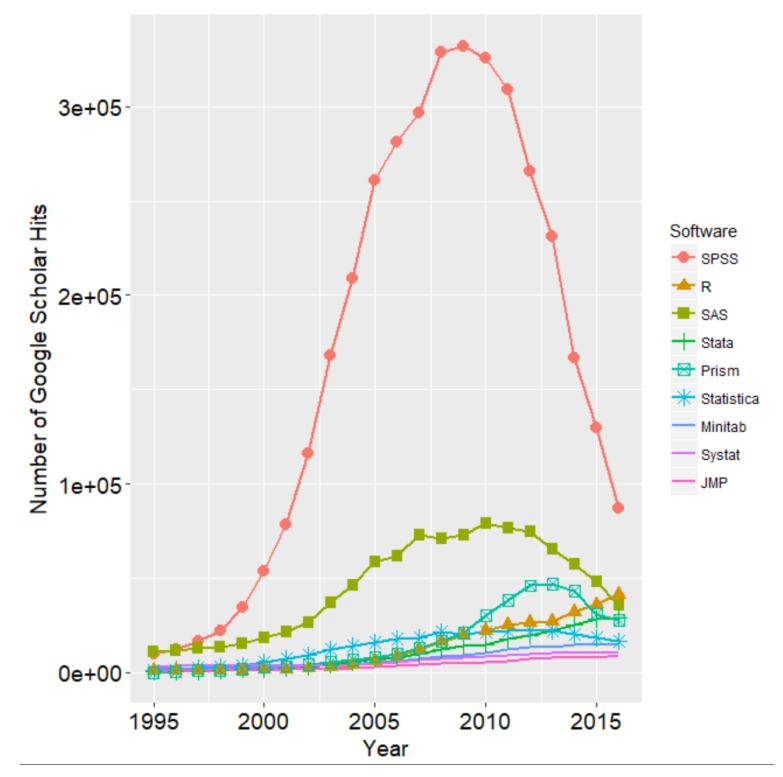

\footnotetext{
${ }^{19} \mathrm{https} / / /$ www.linux.com/news/enterprise-open-source-programs-flourish-tech-and-elsewhere

${ }^{20} \mathrm{http}: / /$ www.computerweekly.com/news/450401822/Open-source-no-longer-scares-the-enterprise
} 
Source: Muenchen (2017), number of articles on Google Scholar, from http://r4stats.com/articles/popularity/

The scale of substitution across the production boundary

These classification issues are not straightforward. Bean (2016, p95-96) writes: "Maintaining a clear distinction as to whether an entity is acting as a consumer or a producer is important for the accurate classification of economic activity." However, the possibility of making a clear distinction is diminishing due to the digitally-enabled changes; the same entity - us - is more easily able to act in both capacities and on an intensive as well as extensive margin. There is, in the examples discussed here, considerable substitution between an existing marketed (digital or non-digital) product and home digital production thanks to the reallocation of time incentivised by digital technologies, just as Becker (1965) discussed. It is obviously the case that if households are undertaking more activities online, they are doing less of something else (Wallsten 2015). However, there is some evidence that the incremental welfare gains and hence incentives to substitute are large, for example in the evidence that households' willingness to pay for broadband connections and digital goods is high (Roston et al 2010, Byrne and Corrado 2017). The scale question, the extent to which such products are substituting for marketed versions, is highly relevant to assessing the productivity puzzle. So too is the issue of new goods prices for the deflators used to calculate real GDP, a question I do not pursue here.

The absence of data oover time $\mathrm{n}$ home production means it is not possible to estimate the scale of digital substitution; we have for the UK, for instance, the 2000 point estimate that on average 197 minutes a day are spent in paid work/commuting and 358 minutes a day in household work. Some earlier work using simple calibrated growth models suggests that including a home production sector and the possibility of time reallocation can make a significant contribution to the evolution of output, including over the business cycle; Benhabib et al (1991) include home production to account better for puzzles in the cyclical behaviour of US output and productivity. Parente and Wright (2000) find that including a home production sector means relatively small percentage distortions to (market) capital accumulation can, depending on other parameter values, account for large differences between output levels in different countries. Greenwood et al (2005) consider the scope of substitution from home to market production due to innovation in domestic technologies, and estimate that about half the increase in women's labour force participation in the US during the $20^{\text {th }}$ century was due to technological progress such as electricity in the home and domestic appliances.

These authors assume standard CES and constant returns functional forms. Individual preferences are given by:

$$
\sum_{t=0}^{\infty} \beta^{t}\left[\ln c_{t}+\alpha \ln \left(1-n_{t}\right)\right]
$$

where 


$$
c_{t}=\left[\mu c_{m t}^{\epsilon}+(1-\mu) c_{n t}^{\epsilon}\right]^{1 / \epsilon}
$$

is a mix of market consumption $c_{m t}$ and non-market consumption $c_{n t}$ while $n_{t}$ is the sum of time spent in market and home work, $\mathrm{n}_{\mathrm{t}}=\mathrm{n}_{\mathrm{mt}}+\mathrm{n}_{\mathrm{nt}}$.

There are home and market production functions:

$$
\begin{gathered}
c_{n t}=k_{n t}^{\phi}\left[(1+\gamma)^{t} n_{n t}\right]^{1-\phi} \\
y_{t}=k_{m t}^{\theta}\left[(1+\gamma)^{t} n_{m t}\right]^{1-\theta}
\end{gathered}
$$

We also require:

$$
y_{t}=c_{m t}+x_{m t}+x_{n t}
$$

Given the exogenous rate of technological change $\Upsilon$, there is a balanced growth path with $n_{m t}$ and $n_{n t}$ constant and market output, market consumption and home consumption as well as the capital stocks $\mathrm{k}_{\mathrm{j}}$ growing at the same rate. The law of motion for the capital stock, for $j=m, n$, is:

$$
k_{j, t+1}=\left(1-\delta_{j}\right) k_{j t}+x_{j t}
$$

It is intuitive in this very simple growth model that a shift into home production will be more likely to occur the larger is $\epsilon$ (substitutability between home and market consumption), and the smaller is $\phi$, (the share of household capital stock). The thought experiment here is what happens to market output $y_{t}$ due to a shift to non-market activity? In the absence of data on non-market time and non-market consumption the model is not identified without strong assumptions about specific functional forms and parameter values (Gronau, 2006). A further consideration is that over the period post-2007, when technology use has shifted so much, the aftermath of the financial crisis will certainly have affected output too. However, an illustration of the potential in theory for quite substantial variation in market output can be gained from varying the elasticity parameter $\epsilon$, holding everything else constant. Other parameters can be set to standard values $\left(\beta=0.98, \gamma=0.02, \delta_{\mathrm{n}, \mathrm{m}}=0.06, \theta=0.33\right)$. If consumer durables excluding houses are taken as the home production capital stock, $\phi=0.10$ might be reasonable. Micro data estimates suggest $\epsilon$ could be $0.4-0.45$ for the US in the pre-digital era (Rupert, Rogerson and Wright 1995, McGrattan, Rogerson and Wright 1997). Table 6 below is simply illustrative of the potential market output relative to the 2000-2007 UK average ${ }^{21}$ as a result of varying this elasticity. This should not be taken as a numerical claim about what has actually happened. However, the model makes the intuition clear: with all due caveats, the effect on measured market output of substitution from market into home production could potentially be significant. This is consistent with other calibrated models which find that the introduction of home production can help explain otherwise puzzling phenomena such as the scale of increased leisure time in the face of income

\footnotetext{
${ }^{21} \mathrm{https}$ //www.ons.gov.uk/economy/grossdomesticproductgdp/datasets/ukquarterlynationalaccountsdatatables
} 
tax differences between countries (Duernecker and Herrendorf, 2018) or inter-country differences in productivity larger than obvious tax distortions would lead one to expect (Parente at al, 2000).

Table 6 Market output as $\epsilon$ varies

\begin{tabular}{|l|l|}
\hline$\epsilon$ & $\begin{array}{l}y_{t} \\
\text { relative to } \\
\text { baseline }\end{array}$ \\
\hline 0.45 & 90 \\
\hline 0.5 & 83 \\
\hline 0.55 & 77 \\
\hline 0.6 & 72 \\
\hline
\end{tabular}

Source: author's calculations

\section{$\underline{\text { Practical data issues }}$}

The discussion here highlights several practical issues for statistical collection.

\section{a) Time use data}

One key data collection requirement to incorporate the output component described above will be the collection of additional household data in the time use survey to understand the labour inputs used to produce these digital intangible goods and services. Any further valuation of household non-market activity involves conceptually the imputed flow of utilised human capital. An extended time use survey will need to distinguish between time spent on online activities for household own-consumption, for leisure, and for 'voluntary' production of digital products. These would need careful piloting to ensure respondents' answers map onto the economic categories. A significant extension of time use surveys would surely require IT-enabled data collection. There is some other existing survey material on people's online activity. For example Ofcom conducted a large-scale one-off survey in 2016 for its 'Digital Day' research. ${ }^{22}$ However, this is focussed on consumption of entertainment and does not include the categories needed for economic analysis. It could also be of interest to capture different activities by demographic categories. Time use data, which is collected based on diaries, would also potentially be able to contribute to measuring the labour supply component of the types of digital activity considered so far - digital DIY intermediation, the sharing economy, and the production of open source digital products. Other potential needs for additional data collection concern the sharing economy (where as noted the ONS already has some work planned). In addition to including new intermediaries in this sector in survey samples, it could be useful to check that the collection of data on incomes and expenditures also includes the sharing economy.

\footnotetext{
${ }^{22}$ http://www.digitaldayresearch.co.uk/media/1083/digital-day-2016-chart-deck-adults-aged-16plusin-the-uk.pdf
} 


\section{b) Valuing digital home production}

If household digital production were to be placed inside the production boundary, like household production of goods, the market value of the use of these digital products would need to be estimated. As all have near-market substitutes, one approach would be to apply, for example, the price of a similar proprietary software package to an open source product, and to an estimated quantity of downloads of the software, although there might of course be immense practical difficulties, not least geo-locating the input activity and the uses or downloads (Nordhaus 2006, Greenstein and Nagel 2015).

\section{c) Intermediate production}

The national accounts are based on a value added approach, whereby the value of intermediate goods used in the production process is deducted from the value of a product or service, in order to avoid double counting. ${ }^{23}$ Byrne and Corrado (2017) provide estimates for the US of capitalised consumer IT durables, and find significant growth in real services from consumer digital assets.

\section{d) Household capital assets}

The use of capital equipment affects household productivity. This is just as true of non-digital household services for own use: someone providing home laundry services is more productive with a washing machine than a mangle. The productivity gain is realised in the form of time saved to engage in other activities, as well as a possible quantity and quality improvement. Digital household services need online access to be possible at all, so households have to purchase computers and install broadband at home. Currently the only household capital asset accounted for in the national accounts is owner occupied housing, because of the imputation included in GDP, and because domestic dwelling investment is captured in $\operatorname{GDP}(\mathrm{E})$. One justification for this is that a home is by far the most valuable asset households ever own. However, the second major asset owned by many households is the car. With a growing proportion of households leasing a vehicle (including through car clubs), and so the scale of the potential switch from ownership to rental or vice versa increasing, a case could be made for including imputed rentals for car owners.

\section{e) Quality improvements}

The substitution from marketed to household account intermediation activities may also involve changes in quality or other characteristics such as wider choice and discovery of variety. Quality change in the case of marketed goods in principle can be captured using hedonic techniques, but in this case that would be harder because there is no price for the replacement (household) intermediation service; although a shadow price for this activity could in principle be hedonically adjusted over time. As with marketed goods, it may be the case that the changes in characteristics are sufficiently large or different in character that they should be considered an increase in consumer surplus due to innovation rather than a quality change in an existing good/service.

\footnotetext{
${ }^{23}$ An aggregate measure that does not deduct intermediate goods is Gross Output, now regularly published for the US by the BEA. See Skousen (1990).
} 


\section{f) Cross-border activity}

Digital activities cross national borders with little friction, yet borders define the collection of statistics, and frame the way productivity is analysed. Many of the types of digital activity considered here are global in their production and consumption. It is not obvious how the contribution of volunteer digital production in the UK alone (say to open source software) can be measured, on the production side, nor how easily the consumption of these digital products in the UK can be measured on the expenditure side. In the case of intermediation services, the transition to digital has led to the substitution of a domestic, bricks and mortar business by an overseas-based online business, which might anyway be using intellectual property or other intangible intra-company transfers to locate its valued added in another country.

\section{$\underline{\text { Discussion and extensions }}$}

I argue, in contrast to some other recent research, that measurement issues due to digital technologies may be making a contribution to the observed marked slowdown in productivity growth since around 2008. This paper has considered the adoption and use of digital technologies by households and businesses involving behaviours that lead to substitutions out of GDP across the production boundary into home production. Digital technology has enabled and incentivised a reallocation of time from market to household. This is not a new phenomenon: safety razors did the same for shaving, while washing machines spurred a substitution of activity in the other direction. However, the potential scale of the current shift in time allocation is quite large, and taking account of time costs therefore may help our understanding of slower measured productivity growth of some market sectors of the economy. Although it is impossible without additional data collection to know the scale of these substitutions, the pieces of available evidence, from the use of free software or Wikipedia usage to the extent of contingent forms of employment, suggest it is large and growing.

This paper has focused on substitutions across the production boundary. The issues arising from the need to select a boundary have been little debated in economics since the early days of the formation of the present System of National Accounts. However, as Simon Kuznets (1947) pointed out in his pioneering work, the selection of what is inside and outside the production boundary is vital for any assessment of long-term growth trends:

"Of the quantitatively impressive growth of total output in this country, as measured in the ordinary estimates of national income, a large part is to be associated with the extension of the business at the expense of the family sector. Consequently, one important prerequisite for a more efficient measurement of economic growth lies in the inclusion of such sectors of production that easily escape the statistical eye. As specific examples we may cite the capital formation involved in the work of American farmers in bringing virgin land into cultivation, or the work within the old- fashioned large family, so much of which has been taken over in recent decades by business firms." 
In other words, he argues that some part of the impressive productivity growth recorded in the mid- $20^{\text {th }}$ century was a measurement artefact due to substitution out of household production into the market, thanks to improvements in domestic technologies. Substitutions are currently occurring in the opposite direction, thanks to digital technologies, and may correspondingly help account for part of the lacklustre real growth performance. Compared to a counterfactual world of no digital activity in home production, substituting for market production, measured productivity will be lower in sectors substituted away from (as in Becker's barbershop example); but productivity measured across both market and household at 'time plus money' prices would be higher. To gain a better understanding of scale will require substantial further data collection, and statistical agencies are just starting to grapple with the needs of measuring the digital economy.

Some researchers have argued that a clear distinction must be made between increases in economic welfare due to innovation (in goods and services or business models) and increases in marketed activities, and that the main effect of digital technologies is simply to increase consumer surplus. For example, in concluding that, "From a conceptual perspective, GDP does not look to be deficient, Ahmad \& Schreyer (2016) put weight on the fact that, "Measures of the total value of consumer welfare such as consumer surplus are at odds with the conceptual basis of measuring GDP." By definition, on this view, zero priced activities should not be taken account of in measuring GDP in nominal or volume terms. Those who advocate this conventional SNA approach do not deny that digital change is important, but their preferred approach would be to extend the household satellite account.

Valuable as it would be, this approach has drawbacks. Although national accountants often describe GDP as simply monetised production, and not an economic welfare measure, this becomes a fiction as soon as it is deflated. The use of any price index is an attempt to create a measure that holds utility constant over time (with well-known challenges about how to achieve this). Real GDP is therefore inherently a welfare concept. As noted above, currently the GDP deflator will be failing to incorporate low and zero prices and so will understate real GDP. To the extent that the deflators are constructed using hedonic methods, adjusting for quality change, the welfare dimension is all the more prominent, for it is not possible to draw a clear boundary between quality changes and consumer surplus (NBER, 1961, cited in Stapleford, 2009, p316). Further research is clearly needed on the implications of digital innovation for price indices.

Others have argued the need for adding welfare enhancements of different kinds to the 'headline' GDP figures (Jones and Klenow, 2016; Jorgenson, 2017). If real terms GDP is useful at all, then perhaps a wider measure of economic welfare would be more useful still, including welfare changes arising from the highly visible changes taking place in the economy at present. This is a big debate, also beyond the 
scope of this paper. It is hardly a new one either, and is well reflected in the 'GDP and Beyond' agenda. ${ }^{24}$

However, the speed and scope of digital transformation has certainly reopened the question of what our conventional statistics can tell us. To reinterpret Robert Solow's famous (1987) comment, it is a paradox that digital is visible everywhere except the productivity figures; big changes that every individual in the OECD economies is experiencing in everyday life do not show up in what everyone takes to be the main indicator of economic progress.

${ }^{24}$ For an introduction, see http://ec.europa.eu/eurostat/web/gdp-and-beyond 


\section{References}

Abdirahman, Mohamed, D Coyle, R Heys, W Stewart, (2017). 'A Comparison of Approaches to Deflating Telecoms Services Output', ESCoE working paper, https://www.escoe.ac.uk/wpcontent/uploads/2017/02/ESCoE-DP-2017-04.pdf

Abraham, Katharine G. and Christopher Mackie, Editors, (2005). Beyond the Market: Designing Nonmarket Accounts for the United States, Panel to Study the Design of Nonmarket Accounts, National Research Council, http://www.nap.edu/catalog/11181.html

Aeppel, Timothy, (2015). “Silicon Valley Doesn’t Believe U.S. Productivity Is Down.” Wall Street Journal, July 17, sec. US.

Ahmad, Nadim. and P. Schreyer (2016). "Measuring GDP in a Digitalised Economy", OECD Statistics Working Papers 2016/07, OECD Publishing, Paris. http://dx.doi.org/10.1787/5jlwqd81d09r-en

Bean, Charles, (2016). Independent Review of Economic Statistics: Final Report. https://www.gov.uk/government/uploads/system/uploads/attachment data/file/507081/2904936 Bean Review Web Accessible.pdf

Becker, Gary S , (1965). 'A Theory of the Allocation of Time', The Economic Journal 75 (299), pp 493-517.

Benhabib, Jess, Richard Rogerson and Randall Wright, (1991) 'Homework in Macroeconomics: Household Production and Aggregate Fluctuations', Journal of Political Economy, Vol 99, no 6, pp1166-1187.

Benkler, Yochai, (2002). 'Some Economics Of Wireless Communications', Harvard Journal of Law \& Technology Volume 16, Number 1, Fall, pp2-59.

Bos, Fritz, (2017). 'Uses of the National Accounts from the $17^{\text {th }}$ century to the present and three suggestions for the future," Eurostat Review of National Accounts and Macroeconomic Indicators, 1/2017, pp 41-72.

Brynjolfsson, Erik, Felix Eggers and Avinash Gannamaneni, (2017), 'Using Massive Online Choice Experiments to Measure Changes in Well-Being', Working Paper, MIT.

Byrne, David M, John G Fernald, Marshall B Reinsdorf, (2016). 'Does the United States have a productivity slowdown or a measurement problem?' Brookings Papers on Economic Activity, Spring 2016, 109-182.

Byrne, David M and Carol Corrado, (2017). 'Accounting for Innovation in Consumer Digital Services, presented at CRIW conference, Washington DC, March 2017.

Coyle, Diane, (2014). GDP: A Brief But Affectionate History, Princeton University Press, Princeton NJ.

Coyle, Diane, (2015). 'Modernising Economic Statistics: Why It Matters,' National Institute Economic Review No. 234 November, F4-F7

Coyle, Diane, (2017). 'Precarious and Productive Work in the Digital Economy', National Institute Economic Review No 240 May 2017, R5-R14.

Coyle, Diane and Timothy Yu-Cheong Yeung, (2017) 'Estimating the Impact on the Hotel Industry of the Rise of Airbnb in Fourteen European Cities,' working paper.

Duernecker, Georg and Berthold Herrendorf, (2018), 'On the Allocation of Time - A Quantitative Analysis of the Roles of Taxes and Productivities', European Economic Review 102 (2018) 169-187. 
EUKLEMS 2017, http://www.euklems.net/

Eurostat, (2003). 'Household production and consumption - Proposal for a Methodology of the Household Satellite Accounts', Statistical working paper, October 2003.

http://ec.europa.eu/eurostat/en/web/products-statistical-working-papers/-/KS-CC-03-003

Folbre, Nancy \& Julie Nelson, (2000). 'For Love or Money?', The Journal of Economic Perspectives, $14: 4,123-140$.

French, Shaun, Andrew Leyshon and Sam Meek, The Changing Geography of British Bank and Building Society Branch Networks, 2003-2012.

http://eprints.nottingham.ac.uk/2199/1/ChangingGeographyofBritishBank\&BuildingSocBranchNetwor ks2003-2012_FINAL.pdf

Gershuny, Jonathan, (2011). 'Time Use Surveys and the Measurement of National Well-Being', Centre for Time Use Research, University of Oxford.

Gershuny, J., Sullivan, O. (2017). United Kingdom Time Use Survey, 2014-2015. [data collection]. UK Data Service. SN: 8128, http://doi.org/10.5255/UKDA-SN-8128-1.

Gordon, Robert, (2016). The Rise and Fall of American Growth, Princeton University Press, Princeton NJ.

Greenstein, Shane and Frank Nagle, (2014). 'Digital dark matter and the economic contribution of Apache', Research Policy, 43, pp623-631.

Greenwood, Jeremy, Ananth Seshadri, and Mehmet Yorukoglu, “Engines of Liberation', (2005) Review of Economic Studies, 72, 109-133.

Griliches, Zvi. (1994). Productivity, R\&D, and the Data Constraint. The American Economic Review, 84(1), 1-23.

Gronau, Reuben (2006), 'Home Production and the Macro Economy: Some Lessons from Pollak and Wachter’, National Bureau of Economic Research Working Papers, 12287.

Groshen, Erica L., Brian C. Moyer, Ana M. Aizcorbe, Ralph Bradley, and David M. Friedman. (2017). "How Government Statistics Adjust for Potential Biases from Quality Change and New Goods in an Age of Digital Technologies: A View from the Trenches." Journal of Economic Perspectives, 31(2): $187-210$

Harrison, Anne, 'Making Services Visible', (1999). paper STD/NA(99)26, OECD. http://www.oecd.org/std/na/2681107.pdf

Jones, Charles, and Peter Klenow, (2016). 'Beyond GDP? Welfare across Countries and Time', American Economic Review, Vol 106, no 9, September, pp 2426-57. http://pubs.aeaweb.org/doi/pdfplus/10.1257/aer.20110236

Jorgenson, Dale, (2017). 'Production and welfare: progress in economic measurement', working paper https://scholar.harvard.edu/files/jorgenson/files/jel_economic measurement_manuscript_revised_5_05 2017.pdf

Jorgenson, Dale (2009), 'A New Architecture for the US National Accounts', Review of Income and Wealth, Series 55, Number 1, March, pp1-42.

Kaldor, N, (1950). 'The Economic Aspects of Advertising', Review of Economic Studies, Volume 18, Issue 1, 1 January, Pages 1-27, https://doi.org/10.2307/2296103

Kuznets, Simon, (1947). 'Measurement of Economic Growth', Journal of Economic History, Vol. 7, 
Supplement: Economic Growth: A Symposium, pp. 10-34

Lerner, Josh and Jean Tirole, (2005). 'The Economics of Technology Sharing:

Open Source and Beyond', Journal of Economic Perspectives, Volume 19, Number 2, Pages 99-120.

McGrattan, Ellen, Richard Rogerson, Randall Wright (1997), 'An Equilibrium Model of the Business Cycle With Household Production and Fiscal Policy', International Economic Review, 38, 267-290.

Mitra-Kahn, Benjamin, (2011). 'Redefining the Economy: A history of economics and national accounting', Ph.D. thesis, City University London. http://openaccess.city.ac.uk/1276/

Muenchen, Robert A, (2017). 'On the Popularity of Data Analysis Software', http://r4stats.com/articles/popularity/

Lacey, James, (2011). Keep From All Thoughtful Men: How US Economists Won World War II, Naval Institute Press.

Nakamura, Leonard and Rachel Soloveichik, (2015). 'Valuing "Free" Media Across Countries in GDP', Working paper 15-25, Federal Reserve Bank of Philadelphia, July 2015.

Nordhaus, William and James Tobin, (1073). 'Is Growth Obsolete?' in Economic Growth, NBER, New York, 1972; also published in Conference on Research in Income and Wealth, Volume 38, Publisher NBER, New York, (1973).

Nordhaus, William, (2004). 'Principles of National Accounting for Non-Market Accounts', in A New Architecture for the US National Accounts, pp143-160, University of Chicago Press.

http://ww.nber.org/chapters/c0135.pdf

Ofcom, Digital Day Research, (2016).

http://www.digitaldayresearch.co.uk/media/1083/digital-day-2016-chart-deck-adults-aged-16plusinthe-uk.pdf

ONS, (2002). 'Household Satellite Account (Experimental) Methodology', Holloway, S, et al, April 2002 .

ONS, (2016a). Household Satellite Accounts 2005-2014, April 2016. (2016a)

ONS, (2016b). 'The feasibility of measuring the sharing economy: progress update', https://www.ons.gov.uk/economy/economicoutputandproductivity/output/articles/thefeasibilityofmeasu ringthesharingeconomy/progressupdate

ONS, (2016c). Measuring output in the Information Communication and Telecommunications industries

https://www.ons.gov.uk/employmentandlabourmarket/peopleinwork/labourproductivity/articles/measur ingoutputintheinformationcommunicationandtelecommunicationsindustries/2016

ONS, Economic Statistics and Analysis Strategy, September 2016,

https://www.ons.gov.uk/methodology/classificationsandstandards/economicstatisticsclassifications/eco nomicstatisticsandanalysisstrategy (2016d)

Parente, Stephen, Richard Rogerson, and Randall Wright, (2000), 'Homework in Development Economics: Home Production and the Wealth of Nations', Journal of Political Economy, Vol 108, No 4, pp 680-687.

Reid, M. (1934). Economics of Household Production. New York: John Wiley

Reinsdorf, Marshall and Paul Schreyer, 'Measuring Consumer Inflation in a Digital Economy', IMF/OECD working paper. 
Rupert, Peter, Richard Rogerson and Randall Wright, (1995), 'Estimating Substitution Elasticities in Household Production Models', Economic Theory, 6, 179-193.

Roston, Gregory, Scott Savage, and Donald Waldman. (2010). "Household Demand for Broadband Internet Service.” B.E. Journal of Economic Analysis and Policy 10 (1): September 9. http://www.degruyter.com/view/j/bejeap.2010.10.1/bejeap.2010.10.1.2541/bejeap.2010.10.1.2541.xml ?format $=$ INT

Skousen, Mark, (1990). The Structure of Production, New York University Press, New York.

Solow, Robert, (1987) 'We'd Better Watch Out', New York Times Book Review July 12, 1987, p36.

Studenski, Paul, (1958). The Income of Nations. New York University Press, New York.

Syverson, Chad, (2016). 'Challenges To Mismeasurement Explanations For The U.S. Productivity Slowdown’, NBER Working Paper 21974, February 2016.

United Nations, (2008). System of National Accounts.

http://unstats.un.org/unsd/nationalaccount/sna2008.asp

United Nations, (1993). System of National Accounts.

http://unstats.un.org/unsd/nationalaccount/sna1993.asp

Waring, Marilyn, (1998). If Women Counted, Harper \& Row.

Vanoli, Andre, (2005). A History of National Accounting, IOS Press, Amsterdam.

Varian, Hal, (2016). 'A Microeconomist Looks At Productivity: A View From the Valley', Brookings Institute presentation September 2016. https://www.brookings.edu/wpcontent/uploads/2016/08/varian.pdf

Von Hippel, Eric (2017), Free Innovation, MIT Press, Cambridge MA.

Wallsten, Scott, (2015). 'What Are We Not Doing When We Are Online?', in Economic Analysis of the Digital Economy, Avi Goldfarb, Shane M. Greenstein, and Catherine E. Tucker, editors, University of Chicago Press, pp55-82. http://www.nber.org/chapters/c13001.pdf 